\section{TONAL VARIATION IN THE LUE DIALECTS OF THAILAND}

\section{Kanita Chaimano ${ }^{1}$}

\begin{abstract}
This study analyzes the tonal variation of Lue dialects spoken in Thailand. These dialects are classified into groups based on structural differences in their tonal systems, and this classification then forms the basis for a linguistic map of Thailand's Lue dialects. The data were collected from 45 villages in 7 provinces in the northern part of Thailand. Three informants were selected to represent each village, for a total of 135 informants participating in this research. William J.Gedney's (1972) wordlist was used to elicit tonal data. The tonal features of the dialects were analyzed using auditory information and the personal computer programs "PRAAT, ver.4.5.12" and Microsoft Excel.
\end{abstract}

My research categorizes the Lue dialects into two major classes with tonal systems consisting of, five and six tones, respectively. Deeper analysis of each dialect's tonal system and tone features supports further division into nine basic patterns (patterns 1-5 with five tones and pattern 6-9 with six tones), with additional subdivisions in pattern 3, 5, 7, and 8. Furthermore, these nine basic patterns may also be organized into five groups based on the tone splits and mergers in column A of Gedney's (1972) tone chart:

${ }^{1}$ Ph.D. Candidate, Department of Linguistics, Mahidol University, Bangkok, Thailand
(1) $A 1-2-3-4(A 1=A 3, A 2=A 4)$, comprising patterns 1 and 6 ;

(2) A1-23-4, comprising patterns 2 and 7,

(3) A1-234, comprising patterns 3 and 8,

(4) A12-34, comprising pattern 4; and

(5) A123-4, comprising patterns 5 and 9.

The tonal system and tone features of pattern 3/2 were found to be distributed widely in many provinces (Chiang Mai, Lamphun, Lampang, and Nan). The tonal system and tone features of patterns 5/1 and $8 / 2$ are found in Chiang Rai province; and those of patterns 4 and 7/1, in Chiang Mai province.

\section{Introduction}

According to Ruengdet Pankhuenkhat's (1988) classification of the Tai language family, Lue has two main dialects: Lue and Yong. Some linguists identify the Lue and the Yong as belonging to a single ethnic group. Indeed linguistically, the Yong living in Thailand are of the same group as the Lue, but both of them call themselves Yong because they originated in Mueang Yong, Myanmar. Maliwan Tuwakham (2005) expands on this by noting that the Yong were originally Lue speakers who migrated from Sipsongpanna to Mueang Yong in the Shan state of Myanmar, where they assumed power over the indigenous people. The Lue then became the majority group in Mueang Yong and renamed themselves Yong after the name of Mueang where they were living. When these Lue were later forced to move to Lamphun, Thailand, they preserved their ethnicity by insisting that they were Yong.

A number of previous studies have investigated the sound systems of Lue and Yong, surveying the languages as they are spoken both in Thailand and in other countries with Lue and Yong populations. 
Because those studies utilized data collected both here and abroad, their phonological analysis differs in terms of consonant phonemes and tonal systems, Tonal systems of Lue and Yong presented in those studies are summarized in tables 1 and 2 .

These previous studies on the tonal system and tone features of both Lue and Yong dialects surveyed dialects in only one location. Comparative studies of Lue and/or Yong dialects from different locations have not yet been conducted. The present study addresses this lack by presenting an overview of the tonal systems of all Lue dialects in Thailand (including Yong dialects as a subclass of Lue), using tonal analysis to classify these dialects, and providing a linguistic map of Lue dialects, which has never been done before.

Table 1: The tonal system of Lue dialects

\begin{tabular}{|c|c|c|c|}
\hline Researcher & Area(s) Studied & $\begin{array}{l}\text { Number } \\
\text { of Tones }\end{array}$ & Tones \\
\hline $\begin{array}{l}\text { Chamnan } \\
\text { Rodhetphai (1974) }\end{array}$ & Chiang Kham, Chiang Rai & 5 & $\begin{array}{l}\text { 1. mid level } \\
\text { 2. low level } \\
\text { 3. high falling } \\
\text { 4. high rising } \\
\text { 5. low rising }\end{array}$ \\
\hline $\begin{array}{l}\text { Seree Veroha } \\
(1975)\end{array}$ & $\begin{array}{l}\text { Ban Yon, Tambon Yong, } \\
\text { Chiang Kham, Chiang Rai }\end{array}$ & 6 & $\begin{array}{l}\text { 1. mid level } \\
\text { 2. low level } \\
\text { 3. high level } \\
\text { 4. high falling } \\
\text { 5. mid rising } \\
\text { 6. low rising } \\
\end{array}$ \\
\hline $\mathrm{Li}(1977)$ & Cheng Tong, Yunnan & 6 & $\begin{array}{l}\text { 1. mid level (22) } \\
\text { 2. mid level (33) } \\
\text { 3. low rising (13) or low } \\
\text { level (11) } \\
\text { 4. high level (55) } \\
\text { 5. mid falling (31) } \\
\text { 6. high rising (25) }\end{array}$ \\
\hline $\begin{array}{l}\text { Nanthariya } \\
\text { Lamchiagdase } \\
\text { (1984) }\end{array}$ & $\begin{array}{l}\text { Ban Hua Fay, Tambon Kluay } \\
\text { Phae, Mueang, Lampang }\end{array}$ & 6 & $\begin{array}{l}\text { 1. mid high falling } \\
\text { 2. low tone } \\
\text { 3. mid falling } \\
\text { 4. high falling } \\
\text { 5. high rising } \\
\text { 6. mid low falling }\end{array}$ \\
\hline $\begin{array}{l}\text { Pornsawan } \\
\text { Ploykaew (1985) }\end{array}$ & Ban Sanmafan, Chiang Rai & 6 & $\begin{array}{l}\text { 1. mid low rising } \\
\text { 2. high level } \\
\text { 3. mid level } \\
\text { 4. mid low level } \\
\text { 5. low level } \\
\text { 6. mid low falling }\end{array}$ \\
\hline
\end{tabular}




\section{Objectives of the study}

The purpose of this study is to analyze the tonal system and tone features of Lue dialects in Thailand. These dialects will be grouped on the basis of comparative tonal data. Then a linguistic map of the dialects will be created based on the tonal systems identified.

Table 2: The tonal systems of Yong dialects

\begin{tabular}{|c|c|c|c|}
\hline Researcher & Area(s) Studied & $\begin{array}{l}\text { Number } \\
\text { of Tones }\end{array}$ & Tones \\
\hline $\begin{array}{l}\text { Ruengdet } \\
\text { Pankhuenkhat } \\
\text { (1978) }\end{array}$ & Pa Sang, Lamphun & 6 & $\begin{array}{l}\text { 1. mid } \\
\text { 2. low } \\
\text { 3. high } \\
\text { 4. falling } \\
\text { 5. rising } \\
\text { 6. low falling }\end{array}$ \\
\hline $\begin{array}{l}\text { Somchit Davies } \\
\text { (1979) }\end{array}$ & $\begin{array}{l}\text { Ban Don Chai, Mae Tha } \\
\text { Valley, Lamphun }\end{array}$ & 6 & $\begin{array}{l}\text { 1. mid level } \\
\text { 2. mid falling } \\
\text { 3. lower low level } \\
\text { 4. high falling } \\
\text { 5. higher low level } \\
\text { 6. rising }\end{array}$ \\
\hline $\begin{array}{l}\text { Mary E Sarawit } \\
(1979)\end{array}$ & $\begin{array}{l}\text { Pa Sang and Makhua Jae, } \\
\text { Lamphun }\end{array}$ & 6 & $\begin{array}{l}\text { 1. mid } \\
\text { 2. low } \\
\text { 3. high falling } \\
\text { 4. mid rising } \\
\text { 5. rising } \\
\text { 6. low falling }\end{array}$ \\
\hline $\begin{array}{l}\text { Wisuttira Neamnark } \\
\text { (1985) }\end{array}$ & $\begin{array}{l}\text { Mueang, Pa Sang, Ban Hong } \\
\text { and Mae Tha, Lamphun }\end{array}$ & 6 & $\begin{array}{l}\text { 1. mid } \\
\text { 2. low rising } \\
\text { 3. high falling } \\
\text { 4. mid rising } \\
\text { 5. mid falling } \\
\text { 6. rising falling }\end{array}$ \\
\hline
\end{tabular}




\section{Methodology}

The theoretical orientation of this study follows Gedney's (1972) checklist for determining tones. The Lue dialects under consideration will be classified on the basis of their tone splits and mergers. In numbering the tones in this research, tones on smooth syllables are numbered, while the tones on checked syllables are treated as allotones of smooth-syllable tones.

The tone features of Thailand's Lue dialects were analyzed using the software program "PRAAT, ver.4.5.12". First, each word uttered was recorded with the program, and then the program calculated the fundamental frequencies and the fundamental frequency curves of each utterance. The results are displayed as the relation between the fundamental frequency and the duration of each tone.

Microsoft Excel was used to plot charts the fundamental frequencies, producing tonal contours for each word. A number system was used to identify the tonal contour of all the Lue dialects.

These results formed the basis for a description the tonal system and tone features of Lue dialects. Comparison of the tonal systems was used to classify the dialects into groups, and these groups were then displayed in language maps.

\section{Research Instruments}

Gedney's (1972) checklist for determining tones has been adapted for this research. The wordlist comprises minimal sets or pairs. For each consonant class, I have selected words which evince the maximum number of similarities across the tone columns so that, in most cases, the only differences among words in a single row are the tones. Such a selection prevents the elicited tonal data from being affected by differences in consonant or vowel sounds and thus producing errors in the tonal analysis.

Table3: A checklist for determining tone in Lue dialects

\begin{tabular}{|c|c|c|c|c|c|}
\hline & A & B & C & DS & DL \\
\hline 1 & $\begin{array}{l}\text { phă: } \\
\text { 'cliff' }\end{array}$ & $\begin{array}{c}\text { phà: } \\
\text { 'to chop' }\end{array}$ & $\begin{array}{l}\text { phâ: } \\
\text { 'cloth' }\end{array}$ & $\begin{array}{c}\mathrm{p}^{\mathrm{h}} \text { àk } \\
\text { 'vegetable' }\end{array}$ & $\begin{array}{l}\text { (nâ:) phà:k } \\
\text { 'forehead' }\end{array}$ \\
\hline 2 & $\begin{array}{c}\text { pa: } \\
\text { 'to throw' }\end{array}$ & $\begin{array}{c}\text { pà: } \\
\text { 'forest' }\end{array}$ & $\begin{array}{l}\text { pâ: } \\
\text { 'aunt' }\end{array}$ & $\begin{array}{c}\text { pàk } \\
\text { 'to stick in' }\end{array}$ & $\begin{array}{c}\text { pà:k } \\
\text { 'mouth' }\end{array}$ \\
\hline 3 & $\begin{array}{c}\text { ba:n } \\
\text { 'to bloom' }\end{array}$ & $\begin{array}{c}\text { bà: } \\
\text { 'shoulder' }\end{array}$ & $\begin{array}{l}\text { bâ: } \\
\text { 'mad' }\end{array}$ & $\begin{array}{l}\text { bàt } \\
\text { 'card' }\end{array}$ & $\begin{array}{l}\text { bà:t } \\
\text { 'to cut' }\end{array}$ \\
\hline 4 & $\begin{array}{c}\mathrm{t}^{\mathrm{h}} \mathrm{a}: \\
\text { 'to rub' }\end{array}$ & $\begin{array}{l}\text { thâ: } \\
\text { 'pier' }\end{array}$ & $\begin{array}{c}\mathrm{t}^{\mathrm{h}} \text { á: } \\
\text { 'to challenge' }\end{array}$ & $\begin{array}{c}\mathrm{t}^{\mathrm{h}} \text { ák } \\
\text { 'to greet' }\end{array}$ & $\begin{array}{l}\mathrm{t}^{\mathrm{h}} \mathrm{a}: \mathrm{k} \\
\text { 'snail' }\end{array}$ \\
\hline
\end{tabular}




\section{Data collection}

The area studied covered seven provinces: Chiang Rai, Chiang Mai, Lamphun, Lampang, Phrae, Nan, and Phayao. These seven provinces contain 37 districts. In most cases, one village was chosen from each district, and three informants were selected to represent each of these villages. This held true for the 29 districts where all speakers identified themselves as Lue. In eight of the districts, however, villagers self-identification divides them into two groups: Lue and Yong. Therefore, two villages were chosen from each of these districts, making 16 villages with three informants each. Villages selected had to meet two linguistic criteria and one nonlinguistic criterion. The linguistic criteria were, first, that the majority of villagers were Lue speakers and, second, that villagers still used Lue for everyday communication both at home and in the local area. The nonlinguistic criterion was that villagers should continue to engage in traditional practices or important ceremonies and rituals, such as the call for the tutelary spirit, the chasing of unlucky past deeds, and the ceremony for good fortune. All told, this produced a total of 45 villages and 135 informants. The informants were all women not less than 50 years old.

\section{Tone comparison of Lue dialects in Thailand}

\section{Comparison of tone numbers}

The tonal systems of the Lue dialects spoken in Thailand have either five or six tones on smooth syllables. The tone splits and mergers in Column A reveal nine tonal patterns.

Table 4: Comparison of tonal patterns with number of tones

\begin{tabular}{|l|c|c|c|c|c|c|c|c|c|}
\hline $\begin{array}{l}\text { Number } \\
\text { of tones }\end{array}$ & 1 & 2 & 3 & 4 & 5 & 6 & 7 & 8 & 9 \\
\hline 5 tone system & $\checkmark$ & $\checkmark$ & $\checkmark$ & $\checkmark$ & $\checkmark$ & & & & \\
\hline 6 tone system & & & & & & $\checkmark$ & $\checkmark$ & $\checkmark$ & $\checkmark$ \\
\hline
\end{tabular}

Table 4 shows that tonal patterns 1, 2, 3, 4, and 5 are five-tone systems, while tonal patterns $6,7,8$, and 9 are six-tone systems.

\section{Tone splits, tone merger, and the complementary distribution of allotones}

All nine tonal patterns are compared in terms of tone splits, tone mergers, and complementary distribution of allotones in Figure 1. 


\begin{tabular}{|c|l|l|l|l|}
\hline A & B & C & DL & DS \\
\cline { 1 - 1 } 1 & & & & \\
\cline { 1 - 1 } 2 & 3 & 4 & 3 & 1 \\
\cline { 1 - 1 } 1 & & & & \\
\hline 2 & 4 & 5 & 4 & 4 \\
\hline
\end{tabular}

Pattern 1

\begin{tabular}{|c|c|c|c|c|}
\hline $\mathbf{A}$ & $\mathbf{B}$ & $\mathbf{C}$ & DL & DS \\
\hline 1 & & & & \\
\cline { 1 - 1 } 2 & 3 & 4 & 3 & 1 \\
2 & & & & \\
\cline { 2 - 5 } & 4 & 5 & 4 & 4 \\
\hline
\end{tabular}

Pattern $3 / 2$

\begin{tabular}{|c|c|c|c|c|}
\hline A & B & C & DL & DS \\
\hline 1 & 3 & 4 & 3 & 1 \\
\hline 2 & 4 & 5 & 4 & 4 \\
\hline
\end{tabular}

Pattern 5/2

\begin{tabular}{|c|l|l|l|l|}
\hline A & B & C & DL & DS \\
\cline { 1 - 2 } 1 & \multirow{2}{*nn}{4} & 5 & 4 & 1 \\
\cline { 1 - 3 } & & & & \\
\cline { 1 - 2 } 3 & 5 & 4 & 5 & 5 \\
\hline
\end{tabular}

Pattern 2

\begin{tabular}{|c|c|c|c|c|}
\hline A & B & C & DL & DS \\
\hline 1 & 3 & 4 & 3 & 1 \\
\cline { 1 - 4 } 2 & & & 4 & 3 \\
\cline { 3 - 5 } & & & & \\
\hline
\end{tabular}

Pattern 4

\begin{tabular}{|c|c|c|c|c|}
\hline A & B & C & DL & DS \\
\cline { 1 - 1 } 1 & \multirow{2}{*nnn}{3} & 5 & 3 & 1 \\
\cline { 1 - 1 } 2 & & & & \\
\cline { 1 - 4 } 2 & 4 & 6 & 4 & 4 \\
\hline
\end{tabular}

Pattern 6

\begin{tabular}{|c|c|c|c|c|}
\hline A & B & C & DL & DS \\
\hline 1 & & & & \\
\cline { 1 - 4 } 2 & 3 & 4 & 3 & 3 \\
\cline { 3 - 5 } & & & & \\
\cline { 2 - 5 } & 4 & 5 & 4 & 4 \\
\hline
\end{tabular}

Pattern 3/1

\begin{tabular}{|c|c|c|c|c|}
\hline A & B & C & DL & DS \\
\hline 1 & 3 & 4 & 3 & 3 \\
\hline 2 & 1 & 5 & 1 & 1 \\
\hline
\end{tabular}

Pattern 5/1

\begin{tabular}{|c|c|c|c|c|}
\hline A & B & C & DL & DS \\
\cline { 1 - 1 } 1 & \multirow{2}{*nn}{4} & 6 & 4 & 4 \\
\cline { 1 - 1 } 2 & 5 & 2 & 5 & 5 \\
\hline
\end{tabular}

Pattern 7/1 


\begin{tabular}{|c|c|c|c|c|}
\hline A & B & C & DL & DS \\
\cline { 1 - 1 } 1 & \multirow{2}{*nnn}{2} & 5 & 4 & 1 \\
\cline { 1 - 1 } 2 & & & 5 & 5 \\
\hline
\end{tabular}

Pattern $7 / 2$

\begin{tabular}{|c|c|c|c|c|}
\hline A & B & C & DL & DS \\
\cline { 1 - 4 } 1 & \multirow{2}{*nn}{4} & 6 & 4 & 1 \\
\cline { 1 - 4 } 2 & & & & \\
\hline 3 & 5 & 2 & 5 & 2 \\
\hline
\end{tabular}

Pattern $7 / 3$

\begin{tabular}{|c|c|c|c|c|}
\hline A & B & C & DL & DS \\
\cline { 1 - 3 } 1 & \multirow{2}{*}{3} & 5 & 3 & 3 \\
\cline { 1 - 1 } 2 & & & & \\
\cline { 3 - 5 } & 4 & 6 & 4 & 4 \\
\hline
\end{tabular}

Pattern 8/1

\begin{tabular}{|c|c|c|c|c|}
\hline A & B & C & DL & DS \\
\hline 1 & & & & \\
\cline { 1 - 1 } 2 & 3 & 5 & 3 & 1 \\
\cline { 3 - 5 } 2 & 4 & 6 & 4 & 4 \\
\hline
\end{tabular}

Pattern $8 / 2$

\begin{tabular}{|c|c|c|c|c|}
\hline A & B & C & DL & DS \\
\hline 1 & 3 & 5 & 3 & 1 \\
\hline 2 & 4 & 6 & 4 & 4 \\
\hline
\end{tabular}

Pattern 9

Figure 1: The nine tonal patterns of Thailand's Lue dialects

Figure 1 shows that the tone splits are conditioned by the phonetic features of the initial consonants. Five types of tone split that are found in tone column A: A1-2-3-4 $(\mathrm{A} 1=\mathrm{A} 3, \mathrm{~A} 2=\mathrm{A} 4), \mathrm{A} 1-23-4, \mathrm{~A} 1-234, \mathrm{~A} 12-$ 34 and A123-4. Tone columns B, C, and D evince two-way splits conditioned by the voicing of the initial consonants.

\section{Tone Column A}

a) Tonal patterns 1 and 6 have a tone split of $\mathrm{A} 1-2-3-4 \quad(\mathrm{~A} 1=\mathrm{A} 3$, $\mathrm{A} 2=\mathrm{A} 4)$.

b) Tonal patterns 2 and 7 have a tone split of A1-23-4.

c) Tonal patterns 3 and 8 have a tone split of A1-234. d) Tonal pattern 4 has a tone split of A12-34.

e) Tonal patterns 5 and 9 have a tone split of A123-4.

2. Tone Column B, C, DL, and DS

All patterns have a two-way split conditioned by the voicing of the initial consonants.

The tone splits in column A have been used to classify Lue dialects since the split in column A differ from the other columns. The Lue dialects may be classified into five groups according to the splits and mergers of tones in column A, as follows. 


\section{Lue dialect group 1 (Patterns 1 and 6)}

In Lue dialect group 1, column A appears as A1-2-3-4 (A1=A3, $\mathrm{A} 2=\mathrm{A} 4)$; that is, it consists of two tones in $\mathrm{A} 1+\mathrm{A} 3$ and $\mathrm{A} 2+\mathrm{A} 4$, respectively. Lue dialects with this tonal arrangement are spoken in Khun Tan District in, Chiang Rai Province, Song Khwae District, Tha Wang Pha District, and Pua District in, Nan Province, Chiang Kham District, Chun District, and Chiang Muan District in, Phayao Province.

\section{Lue dialect group 2 (Patterns 2 and 7)}

In Lue dialect group 2, column A appears as A1-23-4; that is, it consists of three tones $\mathrm{A} 1, \mathrm{~A} 2+\mathrm{A} 3$ and $\mathrm{A} 4$. Lue dialects with this tonal arrangement are spoken in Mae Tha District, Wiang Nong Long District, and Li District in, Lamphun Province, Wiang Kaen District, Phan District, and Wiang Chai District in, Chiang Rai Province, San Sai District, Sameong District, and Doi Saket District in, Chiang Mai Province, Chiang Kham District, Chun District, and Chiang Muan District in, Phayao Province, and Santi Suk District in, Nan Province.

\section{Lue dialect group 3 (Patterns 3 and 8)}

In Lue dialect group 3, column A appears as A1-234; that is, it consists of two tones: $\mathrm{A} 1$ and $\mathrm{A} 2+\mathrm{A} 3+\mathrm{A} 4$. Lue dialects with this tonal arrangement are spoken in Mae $\mathrm{Ai}$ District and Fang District in, Chiang Mai Province, Mae Tha District and Mueang District in, Lampang Province, Mueang District, Thung Hua Chang District, Mae Tha District, and Ban Thi District in, Lamphun Province, Thung Chang District in, Nan Province, and Mae Chan District and Phan District in, Chiang Rai province.

\section{Lue dialect group 4 (Pattern 4)}

In Lue dialect group 4, column A appears as A12-34; that is, it consists of two tones: $\mathrm{A} 1+\mathrm{A} 2$ and $\mathrm{A} 3+\mathrm{A} 4$. Lue dialects with this tonal arrangement are spoken in Mae On District, San Kamphaeng District, and San Pa Tong District in, Chiang Mai Province.

\section{Lue dialect group 5 (Patterns 5 and 9)}

In Lue dialect group 5, column A appears as A123-4; that is, it consists of two tones $\mathrm{A} 1+\mathrm{A} 2+\mathrm{A} 3$ and $\mathrm{A} 4$. Lue dialects with this tonal arrangement are spoken in Chiang Khong District, Chiang Saen District, Mueang District, and Mae Sai District in, Chiang Rai Province, Mueang District in, Phrae Province, Ban Hong District in, Lamphun Province and Phu Sang District in, Phayao Province. 


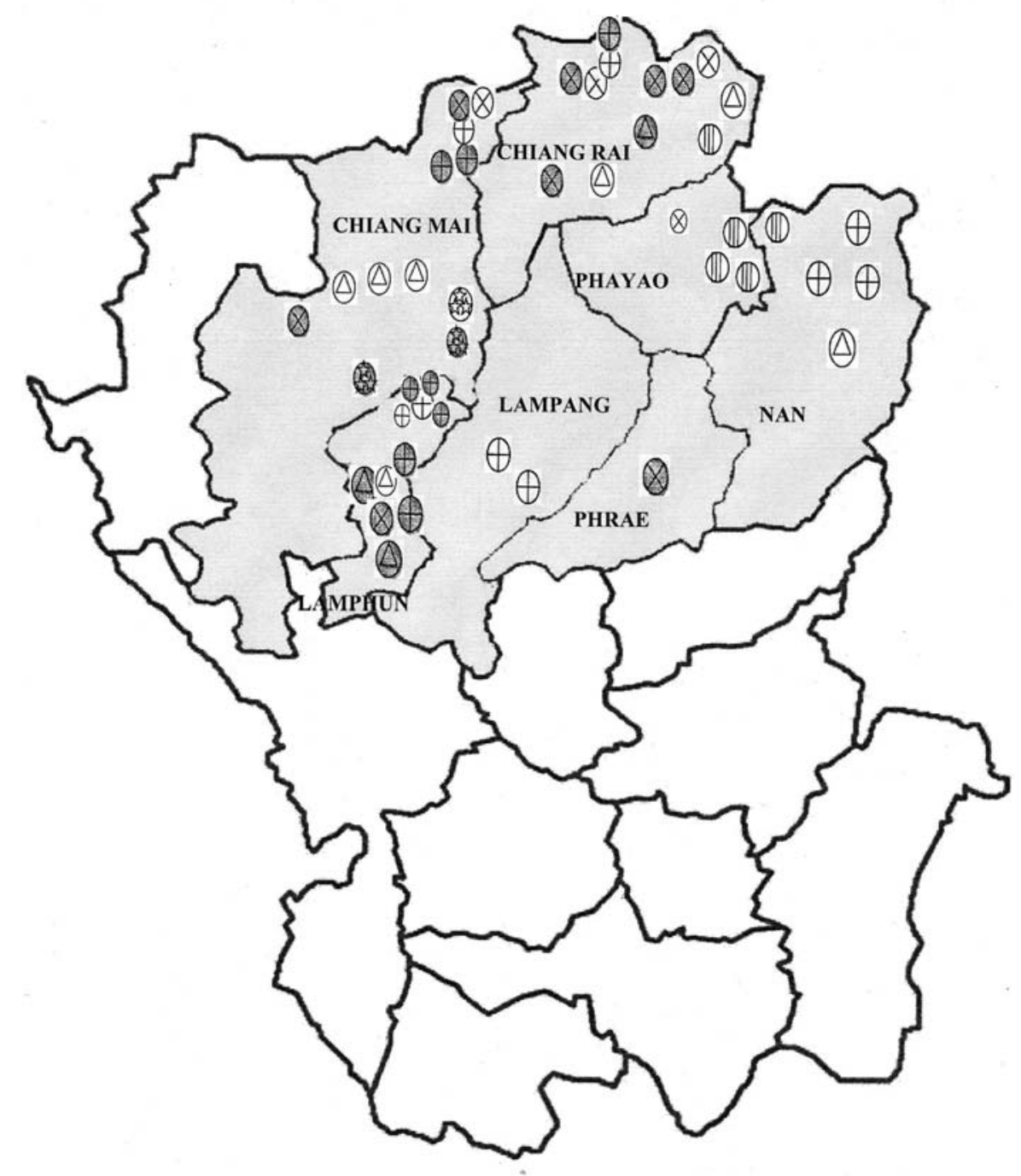

(11) Lue Dialect Group 1 (Tonal Patterns 1 and 6)

(4) Lue Dialect Group 2 (Tonal Patterns 2 and 7)

$\bigoplus \quad$ Lue Dialect Group 3 (Tonal Patterns 3 and8)

Lue Dialect Group 4 (Tonal Pattern 4)

Q Lue Dialect Group 5 (Tonal Patterns 5 and 9)

Light symbol represents Lue dialects, while dark symbol represents Yong dialects.

Map 1: Dialect areas of the five Lue dialect groups based on tone splits and mergers in Column A 


\section{Comparison of tonal contours}

As each dialect may display similarities and differences of tonal contours, this data arrangement shows the tonal contours shared by the informants. The tonal contours of the nine tonal patterns are presented in the tonal diagram as shown in figure 2 .

\begin{tabular}{|c|c|c|c|c|}
\hline $\mathbf{A}$ & B & C & DL & DS \\
\hline$V_{2{ }_{n t}}$ & \multirow{3}{*}{ YN } & \multirow{3}{*}{$\underset{\operatorname{san}}{N h}$} & \multirow{3}{*}{ YN } & \multirow{3}{*}{ YY } \\
\hline $\mathrm{rre}_{\text {sid }}$ & & & & \\
\hline$Y_{n+1}$ & & & & \\
\hline $\begin{array}{l}\text { r卜 } \\
\text { soe }\end{array}$ & 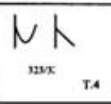 & $r_{x \rightarrow}^{r}$ & $\mathrm{Nh}_{\text {niv }}$ & $\underset{n=1}{N h}$ \\
\hline
\end{tabular}

Pattern 1

\begin{tabular}{|c|c|c|c|c|}
\hline A & B & C & DL & DS \\
\hline 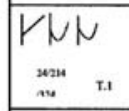 & & & & \\
\hline r & $\underset{\text { sowe }}{N \Lambda}$ & $\begin{array}{l}\text { 人 } \\
32\end{array}$ & $\underset{N=}{N R}$ & $\begin{array}{l}Y \\
* \\
\\
\\
\end{array}$ \\
\hline${ }^{\mathrm{T} 2}$ & $\begin{array}{ll}\lambda_{n} & \\
& \end{array}$ & $\begin{array}{ll}1 \\
\therefore 2\end{array}$ & $\begin{array}{ll} & \\
32 & \end{array}$ & $\begin{array}{ll}{ }_{n} & \\
& \end{array}$ \\
\hline
\end{tabular}

Pattern 3/1

\begin{tabular}{|c|c|c|c|c|}
\hline $\mathbf{A}$ & B & C & DL & DS \\
\hline $\begin{array}{l}\text { WNY } \\
\text { mext } \\
\text { mat }\end{array}$ & & & & \\
\hline$r_{n}$ & $\underset{m \infty}{N R}$ & $\Lambda r$ & $\underset{\text { max }}{N 卜}$ & $Y Y$ \\
\hline $\begin{array}{ll}n \\
n \\
* 2\end{array}$ & $\begin{array}{ll}{ }_{32} & \\
3\end{array}$ & KN & $\begin{array}{lr}{ }_{n} & . \\
& \end{array}$ & 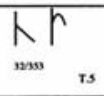 \\
\hline
\end{tabular}

Pattern 2

\begin{tabular}{|c|c|c|c|c|}
\hline A & B & C & DL & DS \\
\hline 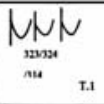 & \multirow[b]{2}{*}{$\mathrm{KN}_{n=0}$} & \multirow[b]{2}{*}{$\underset{\infty}{\wedge}$} & \multirow[b]{2}{*}{ KN } & \multirow[b]{2}{*}{ YNN } \\
\hline$\vdash r$ & & & & \\
\hline$n_{12}$ & 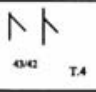 & $n$ & $\begin{array}{l}\text { N卜 } \\
\cdots\end{array}$ & $M \lambda$ \\
\hline
\end{tabular}

Pattern $3 / 2$ 


\begin{tabular}{|c|c|c|c|c|}
\hline A & B & C & DL & DS \\
\hline NN & \multirow{4}{*}{${ }_{n}$} & \multirow{4}{*}{ 卜 } & \multirow{4}{*}{$\begin{array}{l}k \\
n\end{array}$} & \multirow{4}{*}{ YN } \\
\hline nama & & & & \\
\hline r. & & & & \\
\hline \multirow{3}{*}{$r_{w}$} & & & & \\
\hline & $卜$ & KN & 卜 & 人 \\
\hline & $\Rightarrow \quad \tau$ & nox & $2 \pi$ & נז \\
\hline
\end{tabular}

Pattern 4

\begin{tabular}{|c|c|c|c|c|}
\hline A & B & C & DL & DS \\
\hline $\begin{array}{l}N \\
N+ \\
N+\infty \\
N \\
\end{array}$ & $\underset{\operatorname{Nan}}{\mathrm{Nh}}$ & $\stackrel{\text { po }}{\wedge}$ & $\underset{n=n}{N h}$ & 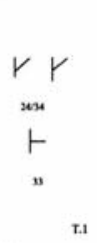 \\
\hline 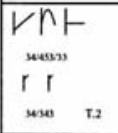 & 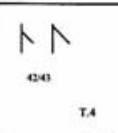 & 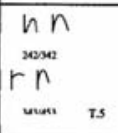 & ${ }_{\infty}^{K \uparrow}$ & 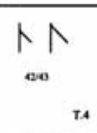 \\
\hline
\end{tabular}

Pattern 5/2

\begin{tabular}{|c|c|c|c|c|}
\hline A & B & C & DL & DS \\
\hline $\begin{array}{ll}N \\
{ }_{24}\end{array}$ & & & & \\
\hline $\begin{array}{l}\text { Kr } \\
\text { 123060 }\end{array}$ & $\underset{n}{N}$ & ${ }_{a}^{1}$ & $\underset{s}{N}$ & $\underset{s}{N}$ \\
\hline$\hat{A}_{4}$ & $F_{3}$ & $\begin{array}{ll}\mathbf{K}_{n} & \\
& \end{array}$ & $F_{33}$ & $F_{n}$ \\
\hline
\end{tabular}

Pattern 7/1

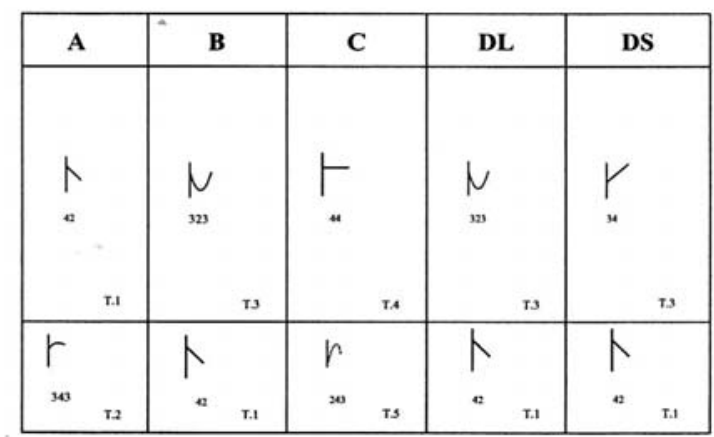

Pattern 5/1

\begin{tabular}{|c|c|c|c|c|}
\hline \multirow{2}{*}{$\begin{array}{l}\text { A } \\
Y r \\
r+1\end{array}$} & B & C & DL & DS \\
\hline & \multirow{3}{*}{$\begin{array}{c}\text { NNN } \\
\text { sumesn } \\
\\
\end{array}$} & \multirow{3}{*}{$\begin{array}{l}\text { NMN } \\
\text { ismome } \\
\end{array}$} & \multirow{3}{*}{$\begin{array}{r}\text { NNN } \\
\text { nanan } \\
\\
\end{array}$} & \multirow{3}{*}{$\begin{array}{l}\text { Y Y } \\
. \\
\end{array}$} \\
\hline 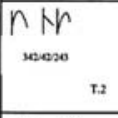 & & & & \\
\hline 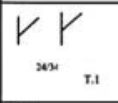 & & & & \\
\hline 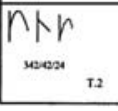 & $\begin{array}{ll}1-r n \\
\text { moen }\end{array}$ & $\begin{array}{lll}h^{\prime} & \\
& & \end{array}$ & $\stackrel{-r n}{-r n}$ & $\underset{\text { masen }}{-r h}$ \\
\hline
\end{tabular}

Pattern 6

\begin{tabular}{|c|c|c|c|c|}
\hline$A$ & B & C & DL & DS \\
\hline $\begin{array}{lll}N & \\
n & .1\end{array}$ & & & - & \\
\hline $\begin{array}{l}r \\
{ }_{3}\end{array}$ & 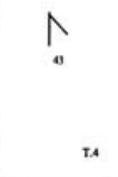 & $K_{n}$ & $\hat{A}_{0}$ & $\begin{array}{l}y \\
*\end{array}$ \\
\hline $\begin{array}{ll}r & \\
4 & \\
\end{array}$ & $\mathrm{X}_{32}$ is & $\begin{array}{ll}Y & \\
* & \text { t. } \\
\end{array}$ & $\begin{array}{l}K_{32} \\
\text { is }\end{array}$ & $\mathrm{K}_{n \quad \text { is }}$ \\
\hline
\end{tabular}

Pattern $7 / 2$ 


\begin{tabular}{|c|c|c|c|c|}
\hline A & B & C & DL & DS \\
\hline $\begin{array}{l}Y Y N \\
\text { 3424214 } \\
\text { 3.1 }\end{array}$ & & & & \\
\hline 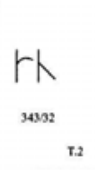 & $\begin{array}{r}N \\
21433\end{array}$ & 人 & $\begin{array}{l}N \\
21633\end{array}$ & 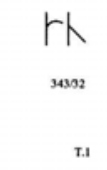 \\
\hline$\eta_{\text {ss }}$ & $\begin{array}{ll}N & \\
\text { os } & \text { is }\end{array}$ & $\begin{array}{ll}\lambda_{32} & \\
n_{2}\end{array}$ & $\begin{array}{lll}N & \\
& \end{array}$ & $\begin{array}{ll}\text { F木 } & \\
& \\
3032\end{array}$ \\
\hline
\end{tabular}

Pattern $7 / 3$

\begin{tabular}{|c|c|c|c|c|}
\hline A & B & C & DL & DS \\
\hline $\begin{array}{l}N N \\
\text { me214 }\end{array}$ & & & & \\
\hline $\begin{array}{l}r \\
=0\end{array}$ & 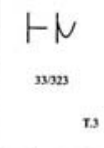 & $\begin{array}{l}Y \\
{ }^{\prime}\end{array}$ & 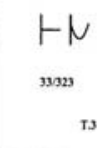 & $\begin{array}{l}Y Y \\
\text { Sint }\end{array}$ \\
\hline$x_{2}$ & 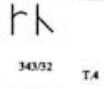 & $\begin{array}{lll}n & \\
\Leftrightarrow & \end{array}$ & $\begin{array}{ll}\text { rh } \\
\sin _{2}\end{array}$ & $\begin{aligned} & r h \\
& \operatorname{sen}_{2}\end{aligned}$ \\
\hline
\end{tabular}

Pattern $8 / 2$

\begin{tabular}{|c|c|c|c|c|}
\hline A & B & C & DL & DS \\
\hline $\begin{array}{l}\text { NY } \\
\text { 201424 }\end{array}$ & & & & \\
\hline $\begin{array}{l}n r \\
\text { sese }\end{array}$ & $\begin{array}{r}\text { NY } \\
\text { sas } \\
\\
\end{array}$ & $\begin{array}{c}K N \\
\text { is } \\
\text { is }\end{array}$ & $\begin{array}{r}\text { NY } \\
\text { sas } \\
\\
\end{array}$ & $\underset{\substack{\text { s. } \\
\text { sass }}}{\text { s. }}$ \\
\hline 12 & ${ }_{n=1}^{\text {h⺊ }}$ & $\begin{array}{ll}n & \\
& \end{array}$ & $\underbrace{h}_{32 s} \vdash$ & $\mid \begin{array}{lll}h & \vdash \\
m & \end{array}$ \\
\hline
\end{tabular}

Pattern 8/1

\begin{tabular}{|c|c|c|c|c|}
\hline A & B & C & DL & DS \\
\hline 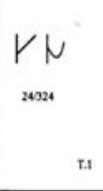 & 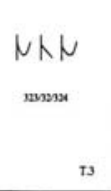 & $\begin{array}{l}\text { YN } \\
\text { is } \\
\\
\\
\end{array}$ & 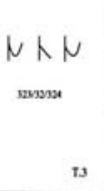 & $\underset{x_{2 x}}{Y Y}$ \\
\hline $\begin{array}{l}n+r \\
{ }_{\text {mese }}^{r}\end{array}$ & $\begin{array}{ll}\vdash \\
n \\
n\end{array}$ & 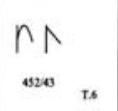 & $\begin{array}{ll}\vdash \\
{ }_{n}\end{array}$ & $\begin{array}{ll}\vdash \\
{ }_{n}\end{array}$ \\
\hline
\end{tabular}

Pattern 9

Figure 2: The tonal contours of the nine Lue tonal patterns

\section{The geographical distribution of the nine Lue tonal patterns}

Each of the Lue tonal patterns is found in various part of Northern Thailand. More specifically, the relevant dialects are spoken in the following seven provinces: Chiang Mai, Chiang Rai, Lamphun, Lampang, Phrae, Nan and Phayao. 

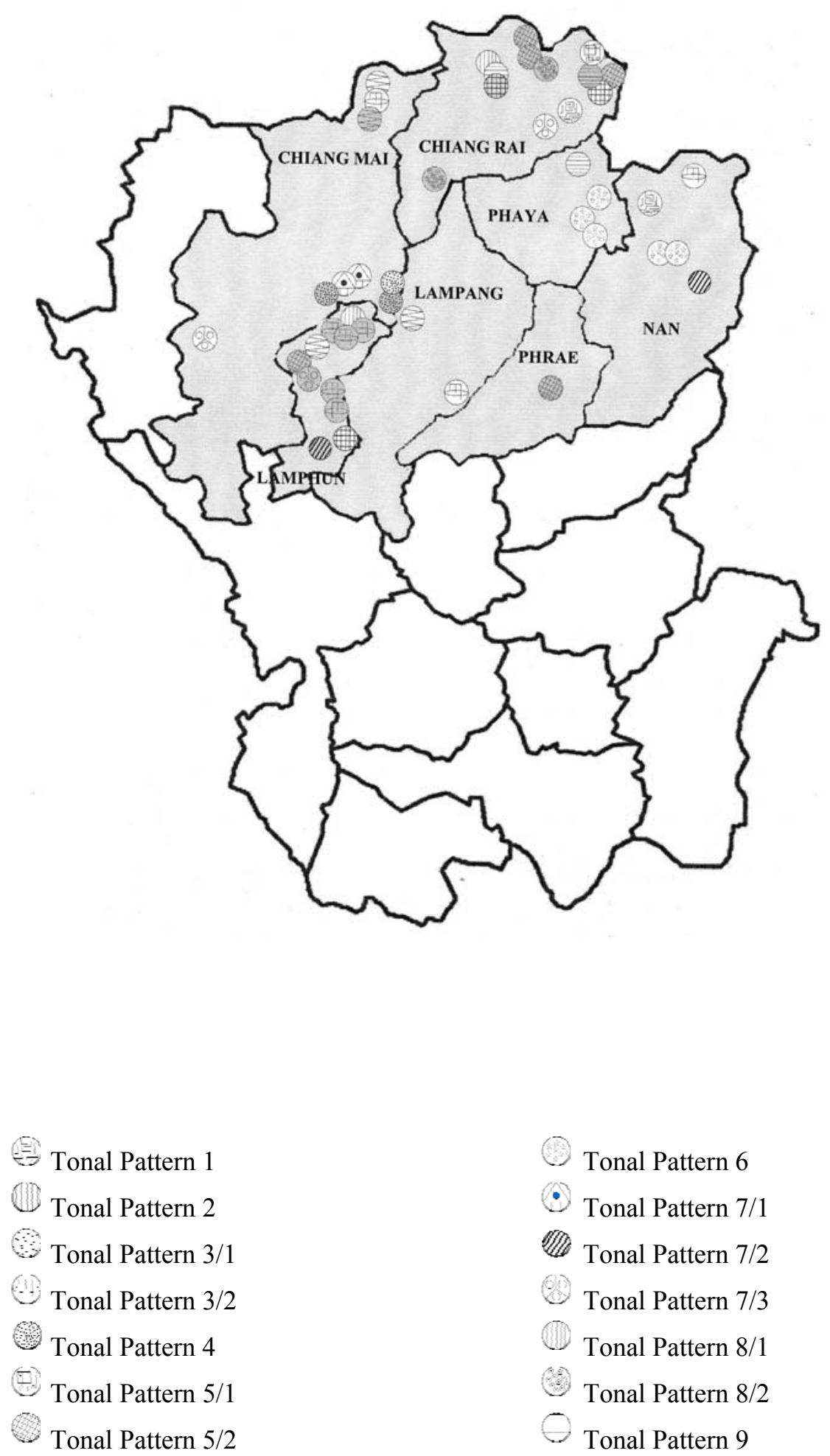

Tonal Pattern 6

- Tonal Pattern 7/1

Tonal Pattern 7/2

Tonal Pattern $7 / 3$

Tonal Pattern 8/1

(9) Tonal Pattern $8 / 2$

$\checkmark$ Tonal Pattern 9

Light symbols represent Lue dialects, while dark symbols represent Yong dialects.

Map 2: Geographical distribution of the nine tonal patterns 


\section{Classification of Lue dialects}

The Lue dialects in Thailand can be classified according to two criteria: (1) the total number of tones and (2) the tone splits and mergers in column A. Based on the number of tones in a dialect's tonal system, the dialects are assigned to one of two groups: Group 1 or Group 2.

\begin{tabular}{|c|c|}
\hline \multicolumn{2}{|c|}{ Classification of Lue dialects } \\
\hline \multicolumn{2}{|l|}{ Group 1 (5 tones) } \\
\hline Ban On Luay (Chiang Mai) & 1) Ban Dong Careon Chai (Chiang Mai) \\
\hline Ban Mai Mok Caam (Chiang Mai) & 2) Ban Luang Tai (Chiang Mai) \\
\hline Ban Huay Luang (Chiang Rai) & 3) Ban Mae Sap Neua (Chiang Mai) \\
\hline Ban Tha Kham (Chiang Rai) & 4) Ban Kluay (Phan, Chiang Rai) \\
\hline Ban Sri Don Chai (Chiang Rai) & 5) Ban Kluay (Mae Chan, Chiang Rai) \\
\hline Ban Muang Ton (Lamphun) & 6) Ban Ko Sai (Chiang Rai) \\
\hline Ban Tha Pladuk (Lamphun) & 7) Ban Pa Paw (Lamphun) \\
\hline Ban Makhue Cea (Lamphun) & 8) Ban Nong Bua (Nan) \\
\hline Ban Kluay Klang (Lampang) & 9) Ban Khon (Nan) \\
\hline D) Ban Mae Pung (Lampang) & 10) Ban Sop Yang (Nan) \\
\hline 1) Ban Pang Puk (Nan) & 11) Ban Yuan (Phayao) \\
\hline 2) Ban Ngop Sala (Nan) & 12) Ban Rong Meat (Phayao) \\
\hline 3) Ban Mittraphap (Chiang Mai) & 13) Ban Thung Careon (Phayao) \\
\hline 4) Ban Don Mai (Chiang Mai) & 14) Ban Sop Pong (Phayao) \\
\hline 5) Ban Don Pin (Chiang Mai) & 15) Ban Kham Sop Puen (Chiang Rai) \\
\hline 6) Ban San How (Chiang Mai) & 16) Ban Pa Pai (Chiang Rai) \\
\hline 7) Ban Chaiphum (Chiang Rai) & 17) Ban Sri Don Moon (Chiang Rai) \\
\hline B) Ban Dok Keaw (Chiang Rai) & 18) Ban Pa Phai Wang Nam Li (Lamphun) \\
\hline 9) Ban Rong Yeaw (Chiang Rai) & 19) Ban Ton Phuang (Lamphun) \\
\hline ) Ban Muang Daeng (Chiang Rai) & \\
\hline ) Ban Chang Khaw Noi Neau (Lam! & \\
\hline Ban Rai (Lamphun) & \\
\hline Ban Thung Khaw Hang (Lamphu & \\
\hline Ban Nong Yang Fa (Lamphun) & \\
\hline $\begin{array}{l}\text { Ban Pa Tan Hong Hae (Lamphun) } \\
\text { Ban Thin (Phrae) }\end{array}$ & \\
\hline
\end{tabular}

Figure 3: Classification of Lue dialects 


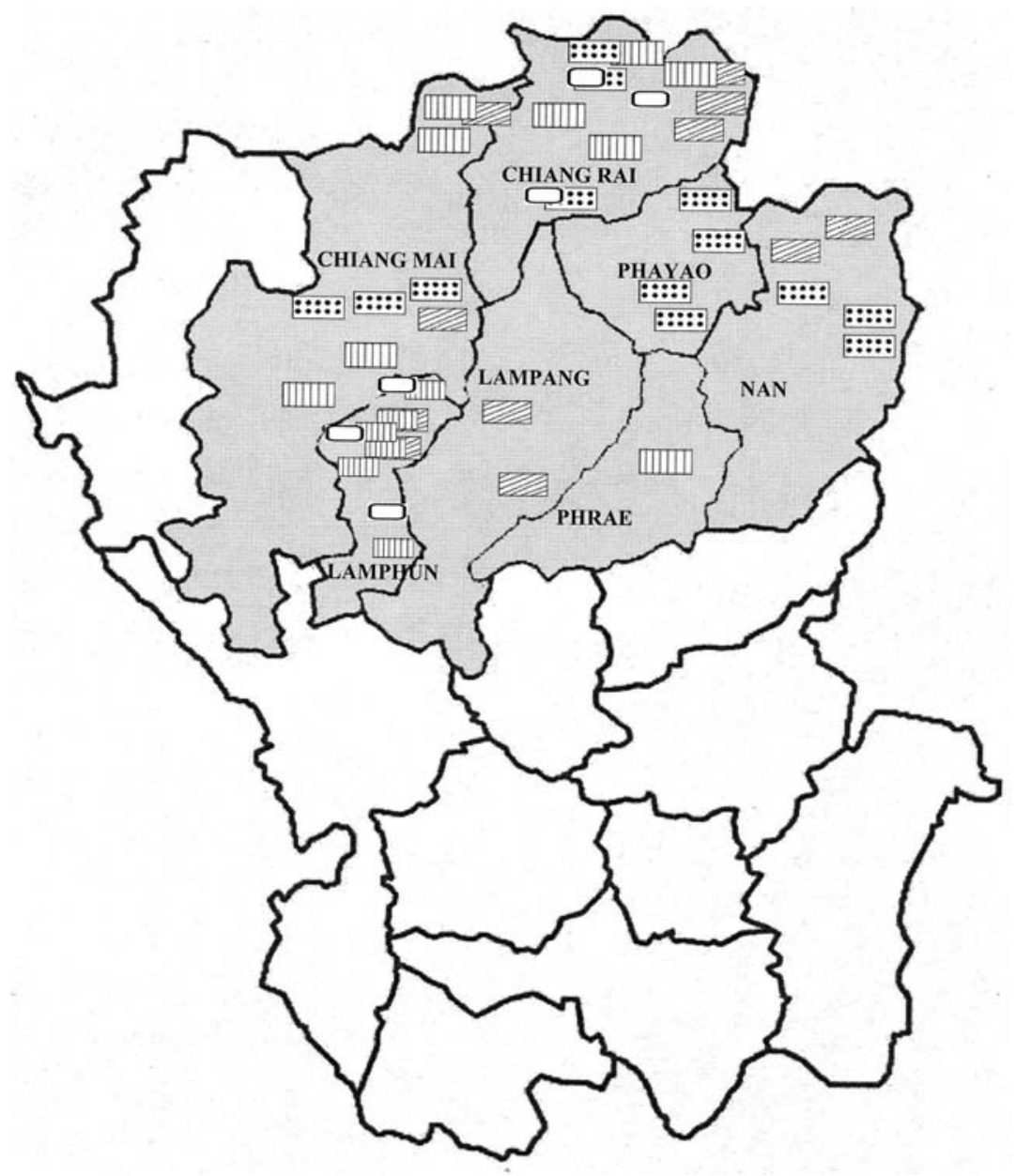

$\begin{array}{lll}\text { 5-Tone systems(Lue) } & \text { ::::: } & \text { 6-Tone systems (Lue) } \\ \text { 5-Tone systems(Yong) } & \text { 6-Tone systems (Yong) }\end{array}$

Due to space limitation, some symbols overlap.

Map 3 : Dialect areas of the two Lue dialect groups based on number of tones 


\section{Conclusion}

This study, has categorized Lue dialects according to the number of tones in their tonal systems. They have then been subcategorized according to the tone configurations of tone column A. Some tonal patterns have been further arranged based on variations in complementary tone distribution.

Based on the number of contrastive tones in their tonal systems, Lue dialects can be classified into two groups: Group 1, with five contrastive tones, and Group 2, with six contrastive tones.

Examination of the tone splits and mergers in column A reveals nine distinct tonal patterns in these Lue dialects. Tonal patterns 1 through 5 belong to the fivetone Group 1. Tonal patterns 6 through 9 belongs to the six-tone Group 2.

\section{Discussion}

The Lue dialects have been classified into two groups based on the tonal systems: the five-tone systems in Group 1 and the sixtone systems in Group 2. Chiang Rai, Chiang Mai, Lamphun, and Nan provinces have dialects from both Group 1 and Group 2. Lampang and Phrae only have dialects from Group 1, while Phayao has only Group 2 dialects. Therefore, it can be concluded that most Lue dialects in Thailand belong to Group 1 .

A classification of the Lue dialects into $\mathrm{P}$ group was carried out by Chamberlain
(1975). His study of the Lue dialects spoken in Chiang Hung Mueang Yong, Ceng Tong, Mueang Sing, Mueang Long, Ou Neua, Kanlampa, Sop Tiek and Houei Lao will be compared with this study. Chamberlain classified a Lue dialect as belonging to the $\mathrm{P}$ group if its tone column *A had a split/merger pattern of *A123-4, and tone column *BCD had a split/merger pattern of $* \mathrm{BCD} 123-4$, with $* \mathrm{~B}=* \mathrm{DL}$.

If one compares the tone split and mergers found in Chamberlain's (1975) analysis of Lue dialects with the splits and mergers found in the Lue dialects of Thailand, one notices the same split/merger configuration in columns BCD (i.e., 123-4) and, similarly, $\mathrm{B}=\mathrm{DL}$. Differences are found only in column A. The Lue dialect studied by Chamberlain in Chiang Hung and Mueang Yong had A12-34, while those in Ceng Tong, Mueang Sing, Mueang Long, Ou Neua, Kanlampa, Sop Tiek, and Houei Lao had A123-4. In contrast, the Lue dialects spoken in Thailand have A1-2-3-4 $(\mathrm{A} 1=\mathrm{A} 3, \mathrm{~A} 2=\mathrm{A} 4), \mathrm{A} 1-23-4, \mathrm{~A} 1-234, \mathrm{~A} 12-$ 34 and A123-4.

A comparison of tone split/merger configurations in the Lue dialects of Chiang Hung and Mueang Yong, on the one hand, and the dialects of Ceng Tong, Mueang Sing, Mueang Long, Ou Neua, Kanlampa, Sop Tiek and Houei Lao, on the other hand, the Lue dialects of Thailand reveals differences in tone configuration of column A and similarities in the tone configurations of columns $\mathrm{B}$, $\mathrm{C}, \mathrm{DL}$, and DS. This is shown in table 5 . 


\begin{tabular}{|l|l|l|}
\hline $\begin{array}{l}\text { Lue in Chiang Hung and } \\
\text { Mueang Yong } \\
\text { (Chamberlain1975) }\end{array}$ & $\begin{array}{l}\text { Lue in Ceng Tong, Mueang } \\
\text { Sing, Mueang Long, Ou Neua, } \\
\text { Kanlampa, Sop Tiek, and } \\
\text { Houei Lao (Chamberlain } \\
1975)\end{array}$ & \\
& A123-4 & \\
\hline A12-34 & B123-4 & A1-2-3-4 (A12=A3, A2=A4), \\
B123-4 & C123-4 & A1-23-4,A1-234, A12-34, and \\
C123-4 & DL123-4 & A123-4 \\
DL123-4 & DS123-4 & B123-4 \\
DS123-4 & B = DL & C123-4 \\
B = DL & & DL123-4 \\
& & DS123-4 \\
& & B = DL \\
\hline
\end{tabular}

Table 5: Comparison of Chiang Hung and Mueang Yong Lue and, Ceng Tong, Mueang Sing, Mueang Long, Ou Neua, Kanlampa, Sop Tiek, and Houei Lao Lue with the Lue dialects of Thailand

Considering the historical evidence, Sawaeng Malasaem (1997: 40) notes that Tai Lue culture is spread all along the Mekong River, the Kok River, and the upper part of the Ping River. This area consists of many important cities, such as Chiang Rung, Mueang Luang, Mueang La, Chiang Tung, Mueang Yong, Chiang Khaeng, Mueang Sing, Chiang Saen, Chiang Khong, Mueang Fang, and cities that act as provincial capitals in Thailand today: Chiang Rai, Chiang Mai, Lamphun, Lampang, Phrae, Nan and Phayao. Thus, it is not surprising to find Lue and Yong dialects only in the northern part of Thailand and covering only these seven provinces.

We should note that the Lue and the Yong constitute a single people who settled in
Sipsongpanna and that the reason why they refer to themselves by different names is that they migrated to Thailand from different places: the Lue from Sipsongpanna and the Yong from Mueang Yong, Myanmar.

The next question to be considered concerns the variation of the Lue and Yong dialects. Why do some provinces have both Lue and Yong dialects, while other provinces have only one or the other?

This study showed that Chiang Rai, Chiang Mai, and Lamphun Provinces have both Lue and Yong dialect communities, while Lampang, Phayao, and Nan Provinces have only Lue dialects and Phrae Province has only Yong dialects. 
Teeraparb Lohitkun's (1995: 96) history of the Tai Lue notes that King Kawila was assigned to bring Tai Lue people from Sipsongpanna into Chiang Mai and other provinces in Northern Thailand during the reign of King Rama I, forcing the Yong to move from their homeland in Mueang Yong, Myanmar, to settle in Lamphun. Therefore, we find both Lue and Yong dialects in Chiang Mai and Lamphun provinces. Furthermore, Teeraparb's historical evidence is consistent with this study's finding that Lue is spoken more than Yong in Chiang Mai and Yong more than Lue in Lamphun.

Geographically speaking, Chiang Mai, Phayao, and Nan border close to Myanmar and form the routes to Sipsongpanna, the homeland of Lue. Therefore, Chiang Rai is the province in which the Lue dialects first entered Thailand. Even though both Lue and Yong dialects are found in Chiang Rai, Lue is more widespread. Lue dialects are found in Phayao and Nan and also, by virtue of its geographical proximity, in Lampang. Phrae Province borders Lampang, Phayao, and Nan. As Lue dialects are spoken in these three provinces, one would also expect to find them spoken in Phrae, but this is not the case. Only Yong is found in Phrae, and that only in Ban Thin, Muaeng District. Interviews conducted in the course of this research revealed that the Yong in Phrae came from Lamphun. So, this again explains why Yong and not Lue is spoken there.

The Lue dialects spoken in Thailand today have been influenced by Standard Thai and Kham Mueang. The older generation are able to code switch i.e. they speak Lue among themselves but Standard Thai or Kham Mueang with their children. The Lue dialects will mostly like be transformed or lost to varying degrees in the future. The
Thai government should play a role in promoting language preservation.

\section{References}

Chamberlain, James. 1975. A New Look at the History and Classification of the Tai Language. Harris and Chamberlain 1975: 49-66.

Chamnan Rodhetphai. 1974. An annotated collection of Thai-Lue Folktales (วรรณกรรมไทยลื้อ). Bangkok:

Supervisory Unit, Department of Education Bangkok Metropolitan administration. (In Thai)

Gedney, William J. 1972. A Checklist for Determining Tones in Tai Dialects. In Studies in Linguistics in Honor of George L. Trager, edited By M. Estellie Smith, pp. 191-205. The Hague: Mouton.

\section{Li, Fang Kuei. 1977. A Handbook of Comparative Tai. Honolulu: University Press of Hawaii.}

Maliwan Tuwakham. 2005. Language Vitality and Language Attitude among the Yong People in Lamphun Province: A Sociolinguistic Study. M.A. thesis in Linguistics, Faculty of Graduate Studies, Payap University.

Nanthariya Lamchiagdase. 1984. The Phonology of Lue in Lampang Province. M.A.thesis in Linguistics, Faculty of Graduate Studies, Mahidol University.

Pornsawan Ploykaew. 1985. The Phonology of Lue in Chiangrai Province. M.A.thesis in Linguistics, 
Faculty of Graduate Studies, Mahidol University.

Ruengdet Pankhuenkhat. 1978. Yong Phonology. Bangkok: Southeast Asian Language Center, Faculty of Graduate Studies, Mahidol University.

---. 1988. Thai Dialects (ภาษาถิ่นตระกูลไท). Institute of Language and Culture for Rural Development, Mahidol University. (In Thai)

Sarawit, Mary E. 1979. Syllabic $m$ in Two Yong Dialects. In Studies in Tai and Mon-Khmer Phonetics and Phonology In Honor of Eugenie J.A. Henderson, edited By Theraphan et al, pp. 163170. Bangkok: Chulalongkorn University.

Sawaeng Malasaem. 1997. Ethnolinguistic Map of Thailand (แผนที่ภาษาของชาติพันธุ์ ต่างๆในประเทศไทย). Bangkok: Office of the National Culture Commission. (In Thai)

Seree Veroha. 1975. Lue Tones (เสียง วรรณยุกต์ในภาษาลื้อ). In Studies in Tai Linguistics In Honor of William J.Gedney, edited By Harris and Chamberlain, pp. 387-419. Bangkok: Central Institute of English Language, Office of State University. (In Thai)

Somchit Davies. 1979. A Comparative Study of Yong and Standard Thai. In Studies in Tai and Mon-Khmer Phonetics and Phonology In Honor of Eugenie J.A. Henderson, edited By Theraphan et al, pp. 26-48. Bangkok: Chulalongkorn University.
Teeraparb Lohitkun. 1995. Tai in Southeast Asia. Bangkok: Manager.

Wisuttira Neamnark. 1985. Lamphun Yong Phonology: A Synchronic Comparative Study (ระบบเสียงภาษายองซึ่ง พูดในจังหวัดลำพูน: การศึกษาเปรียบเทียบ แบบร่วมสมัย), Doctoral thesis in Linguistics, Faculty of Graduate Studies, Chulalongkorn University. (In Thai) 